\title{
Microplastic Identification in the Faeces of Pregnant Women
}

\author{
Ervina Septami AR ${ }^{1}$, Hasnawati Amqam ${ }^{1 *}$, Sitti Maisuri Tadjuddin Chalid ${ }^{2}$, Anwar Daud ${ }^{1}$, Hasanuddin Ishak ${ }^{1}$, Stang $^{3}$
}

${ }^{1}$ Department of Environmental Health, Faculty of Public Health, Hasanuddin University, Indonesia

${ }^{2}$ Obstetrics and Gynecology Division, Fetomaternal Division, Faculty of Medicine, Hasanuddin University, Indonesia

${ }^{3}$ Department of Reproductive Health, Faculty of Public Health, Hasanuddin University, Indonesia

DOI: $10.36348 /$ sjbr.2020.v05i11.003 | | Received: 21.10.2020 | Accepted: 05.11.2020 | Published: 06.11 .2020

*Corresponding author: Hasnawati Amqam

\section{Abstract}

Microplastics come from various types of materials in the form of pieces, fibres, fragments, granules, slabs, or tiny flakes between 0.1-5000 $\mu \mathrm{m}$. It is very resistant to degradation and is insoluble in water. Microplastics are widely distributed in the oceans, sediments, land, and consumed by marine organisms such as fish and shellfish. This study aims to describe the presence of microplastics in the faeces of pregnant women. This type of research is an analytic observation with a cross-sectional design. The sample in this study amounted to thirty pregnant women. Data obtained through interviews using a questionnaire and examination of faeces samples. The results showed that all stool samples contained microplastics. The number of microplastics found ranged from 5 to 21 microplastics with the types of fiber, fragments, and films. The length of the microplastics ranges from $0.2-4.9 \mathrm{~mm}$. It is concluded that ingested microplastics are disposed of through feces but the residue will accumulate in the body and can pose health risks in the long term. Encouraging the role of the government through education and regulation so that the community obeys and does not throw garbage anywhere.

Keywords: Microplastic, Seafood, Amount, Type, Size.

Copyright (C) 2020 The Author(s): This is an open-access article distributed under the terms of the Creative Commons Attribution 4.0 International License (CC BY-NC 4.0) which permits unrestricted use, distribution, and reproduction in any medium for non-commercial use provided the original author and source are credited.

\section{INTRODUCTION}

Plastic has become a global issue due to its continuous growth over time. Plastics come from various products that are initially difficult to decompose by microorganisms and are very resistant to degradation [4]. High population in urban areas are one of the leading causes of the increasing volume of plastic waste [18]. Accumulation, generally in open dumps, is associated with environmental pollution [14]. In terms of manufacture, plastics are dominated by polymers of polystyrene, polyethylene, polypropylene, polyvinyl chloride, and polyethylene terephthalate [20]. The increase of plastic-based materials results in around 360 million tons of microplastic pollution. Asia occupies the world highest production of plastic waste by $51 \%$ [21]. It is estimated that more than 5 trillion pieces of plastic float in the oceans worldwide weighing more than 250,000 tons, which is scientifically harmful to aquatic ecosystems.

The long degradation of plastics has resulted in microplastics which are a combination of various types of materials, which can be pieces, fibres, granules, slabs, or tiny flakes between $0.1-5000 \mu \mathrm{m}$ [11]. The degradation process that occurs by external forces such as wind, ocean currents, and waves causes plastic waste to be fragmented into smaller pieces through weathering, including exposure to UV rays and biodegradation [9]. Plastic waste is widely distributed in water, sediment, fish, shellfish, soil, and even air [13]. Materials that were degraded to microplastics (MPs, $<5 \mathrm{~mm}$ ) were found as fibres, fragments, films, and nano plastics (NP; particles < $0.1 \mu \mathrm{m} ; 100 \mathrm{~nm}$ ) [26], whereas the size of microplastics presented at sea level, sediments and biota measuring < 1- 1-5 mm [19].

Microplastics are defined as primary and secondary microplastics based on their respective characteristics. Primary microplastics are small plastics that are made in such a way, deliberately added to cosmetic products, cleaning agents, and skin exfoliants, which can enter the environment through sewage treatment plants, ship paints, and building cleaners. Secondary one when it comes from physical and chemical degradation of plastic waste [17].

Microplastics are widespread and ubiquitous in marine habitats from surfaces and coastlines to deep seas. Small pieces can be absorbed by small biota ranging from fish to shellfish, which have the potential 
to cause damage $[27,10]$. The source of pollution is not only from ordinary microplastics, but fish contaminated with fibre also comes from fishing gear/ropes or nets used by fishermen [7]. Micrometre-sized plastics are easier to digest while nanometers can pass through cell membranes [15]. More than 690 contaminated marine species have been detected in their digestive tract and represent possible routes of exposure to humans [5, 24].

Fish is very beneficial for pregnant women and fetal growth. Fish contribute $180 \mathrm{kcal}$ per person per day of energy in food. Fish contains protein, polyunsaturated fatty acids (PUFA), fats (omega-3, fatty acids eicosapentaenoic acid (EPA), docosehexaenoic acid/DHA), some vitamins, and minerals that essential for fetuses and infants neurodevelopment [25].

Various colours, shapes and sizes of microplastics were detected in all fish muscle samples. estimated mean of microplastic intake throgh fish muscles of white shrimp, Grouper, yellow tail fish, and Barracuda consumption was 555, 240, 233, and 169 items/300 g-week. Fish has higher microplastic content in muscles [1]. The density of most microplastics is higher than seawater $(1.02 \mathrm{~g} / \mathrm{cm} 3)$ and settles in sediments [2]. The purpose of this study is to describe the presence of microplastics in the faeces of pregnant women.

\section{MATERIALS AND METHODS \\ Location and research design}

This research was conducted in the working area of Public health center Pattingalloang and Jumpandang Baru, Makassar City. The research was conducted from June to August 2020. This type of research is observational descriptive.

\section{Sample}

There were thirty pregnant women who were involved in this study. They are pregnant women who visit Public health center Pattingalloang and Jumpandang Baru, Makassar City. They were involved with several inclusion criteria, that is

a. Respondents were pregnant women who visited the Public health center

b. Respondents are domiciled in Makassar City

c. Respondents from the beginning of their pregnancy checked themselves at the Public health center Pattingalloang and Jumpandang Baru

\section{Data collection}

The data collection method in this study is an interview with a questionnaire. Examination of stool samples is carried out in the laboratory.

\section{Data analysis}

The data analysis used in this research is descriptive analytic data analysis, which is to describe the amount of seafood consumed, and the microplastics found in the feces of pregnant women.

\section{RESULTS \\ Respondent Characteristics}

Table-1: Distribution of Pregnant Women based on Characteristics in Pattingalloang Village and Ujung Pandang Village, Makassar City in 2020

\begin{tabular}{|c|c|c|}
\hline \multirow{2}{*}{ Variable } & \multicolumn{2}{|c|}{ amount } \\
\cline { 2 - 3 } Age (Years) & $\mathbf{n}$ & $\mathbf{\%}$ \\
\hline 20 & 5 & 16.7 \\
\hline $20-30$ & 15 & 50 \\
\hline $30-35$ & 5 & 16.7 \\
\hline $35-40$ & 4 & 13.3 \\
\hline $40-45$ & 1 & 3.3 \\
\hline Total & $\mathbf{3 0}$ & $\mathbf{1 0 0}$ \\
\hline Gestational Age & $\mathbf{n}$ & $\mathbf{\%}$ \\
\hline 1st trimester & 11 & 36.7 \\
\hline 2nd trimester & 17 & 56.7 \\
\hline 3rd trimester & 2 & 6.6 \\
\hline Total & $\mathbf{3 0}$ & $\mathbf{1 0 0}$ \\
\hline
\end{tabular}

Table 1 shows the characteristics of the respondents based on age and gestational age. Most respondents were 20-30 years old (50\%), and the lowest was $40-45$ years $(3.3 \%)$. Furthermore, most respondents had a gestational age of the second trimester $(56.7 \%)$, followed by third-trimester gestation age $(6.6 \%)$ and first pregnancy age $(36.7 \%)$.

\section{Microplastics and Seafood Consumption}

Table-2: Distribution of Pregnant Women Based on the Amount of Consumption and Type of Seafood Consumed in Pattingalloang and Ujung Pandang Villages, Makassar City in 2020

\begin{tabular}{|c|c|c|}
\hline \multirow[t]{2}{*}{ Variable } & \multicolumn{2}{|c|}{ Amount } \\
\hline & $\mathbf{n}$ & $\%$ \\
\hline \multicolumn{3}{|l|}{ Amount of seafood consumption } \\
\hline High & 13 & 43.3 \\
\hline Moderate & 7 & 23.3 \\
\hline Low & 10 & 33.3 \\
\hline Total & 30 & 100 \\
\hline $\begin{array}{l}\text { The type of seafood that is often } \\
\text { consumed }\end{array}$ & $\mathbf{n}$ & $\%$ \\
\hline Big fish & 5 & 17 \\
\hline Small fish & 18 & 60 \\
\hline Not Fish & 7 & 23 \\
\hline Total & 30 & 100 \\
\hline Number of microplastics & $\mathbf{n}$ & $\%$ \\
\hline$<12$ & 18 & 60 \\
\hline$>12$ & 12 & 40 \\
\hline Total & 30 & 100 \\
\hline
\end{tabular}

Table 2 shows the variables of the amount of seafood consumption, the type of seafood and the number of microplastics. More respondents have high 
seafood consumption (> 12 ounces/mg) in a week $(43.3 \%)$ than low consumption $(33.3 \%)$ and moderate consumption $(23.3 \%)$. The type of seafood most frequently consumed by respondents in a week is small fish $(60 \%)$, followed by shrimp and squid $(23.3 \%)$ and big fish $(16.7 \%)$. The highest number of microplastics found in the feces of pregnant women was $<12(60 \%)$ and $>12(40 \%)$.

\section{DISCUSSION}

Microplastics are plastic particles $<5 \mathrm{~mm}$ in size found in the feces of pregnant women. One of the causes of microplastics found in the feces of pregnant women is the consumption of seafood contaminated by plastic waste. Micro plastics were found in thirty stool samples ranging from 5-21 microplastics.

Seafood is a significant source of omega-3 fatty acids which are essential for optimal neurodevelopment. However, a study conducted by Avon Longitudinal Study of Parents and Children (ALSPAC) using the longitudinal method suggested that pregnant women should limit their fish intake to only 340 grams every week [12]. This research is in line with recommendations from the FDA EPA that pregnant women consume seafood in a week of between 8 and 12 ounces per week. A study by Avio et al. [3] stated that microplastics absorb toxins produced from chemicals in seawater and the surrounding environment and can be transferred into the food chain indirectly. This result is in line with research Rochman et al (2015) [22] found that the accumulation of microplastics in the sediment also make the biota consume microplastics directly. If humans consume contaminated biota, the microplastics will again enter the human body.

The results of research by Rochman et al. [22] at the Makassar Paotere fish Auction show that microplastics are found in various types of fish, including Mackerel, Flying fish, Herring, Carangidae and Baronang fish. Research by Devriese et al. [6] on shrimp explained that synthetic fibres dominated microplastics with a concentration of $1.23 \pm 0.99$ microplastics per shrimp. The same thing was also conveyed in the research of Margaretha [16], which identified microplastics in squid samples obtained from markets in Semarang. The results were particles/gram of wet weight found 3.31-3.88 and 0.77-0 microplastics with fibre and fragment types.

Humans are potentially exposed to microplastics through food, drink and air (9). A number of studies have shown that microplastics can pass through the food chain and then enter the human body. Consumption of seafood is one possible pathway for exposure to microplastics in humans [24].

A research by Schwab et al. [23] detecting microplastics in human feces found that 8 samples of human faeces were analyzed by FTIR, all containing microplastics ranging in size from 50-500 $\mu \mathrm{m}$. Most of the microplastics identified were in the form of fragments and films. The results of this study on thirty samples of feces of pregnant women in the working area of Public health center Pattingalloang and Jumpandang Baru found that all samples contained microplastics with sizes ranging from $0.2-4.9 \mathrm{~mm}$.

\section{CONCLUSION}

Based on the research results, it can be concluded that microplastics were found in all stool samples of pregnant women. Microplastics were found from thirty stool samples ranging from 5-21 microplastics with the types of fibre, fragments and films. The length of the microplastics varies from 0.2 $4.9 \mathrm{~mm}$. The kinds of seafood consumed by the respondents were large fish (tuna and skipjack), small fish (fly, mackerel and anchovies), and non-fish (squid and shrimp).

Things that need to be done are to change habits by reducing, reusing and recycling plastics gradually by avoiding using or purchasing single-use plastik products in everyday life encouraging the role of government through education and regulation. Carrying out beach clean-up activities can increase public awareness to protect the marine environment by not littering.

\section{REFFERENCES}

1. Akhbarizadeh, R., Moore, F., \& Keshavarzi B. (2018). Investigating a Probable Relationship Between Microplastics and Potentially Toxic Elements in Fish Muscles from Northeast of Persian Gulf. Environmental Pollution, 232:54-63.

2. Alomar, C., Estarellas, F., \& Deudero, S. (2016). Microplastics in the Mediterranean Sea: deposition in coastal shallow sediments, spatial variation and preferential grain size.Marine environmental research, 115, 1-10.

3. Avio, C. G., Gorbi, S., Milan, M., Benedetti, M., Fattorini, D., d'Errico, G., \& Regoli, F. (2015). Pollutants bioavailability and toxicological risk from microplastics to marine mussels. Environmental Pollution, 198, 211-222.

4. Bergmann, M., Gutow, L., \& Klages, M. (2015). Marine anthropogenic litter (p. 447). Springer Nature.

5. Carbery, M., O'Connor, W., \& Palanisami, T. (2018). Trophic transfer of microplastics and mixed contaminants in the marine food web and implications for human health. Environment international, 115, 400-409.

6. Devriese, L. I., Van der Meulen, M. D., Maes, T., Bekaert, K., Paul-Pont, I., Frère, L., \& Vethaak, A. D. (2015). Microplastic contamination in brown shrimp (Crangon crangon, Linnaeus 1758) from coastal waters of the Southern North Sea and Channel area. Marine pollution bulletin, 98(1-2), 
179-187.

7. Dowarah, K., \& Devipriya, S. P. (2019). Microplastic prevalence in the beaches of Puducherry, India and its correlation with fishing and tourism/recreational activities. Marine pollution bulletin, 148, 123-133.

8. EPA. (2019). Advice About Eating Fish. Food \& Drug Administration. Environmental Protection Agency.

9. Eriksen, M., Lebreton, L. C., Carson, H. S., Thiel, M., Moore, C. J., Borerro, J. C., \& Reisser, J. (2014). Plastic pollution in the world's oceans: more than 5 trillion plastic pieces weighing over 250,000 tons afloat at sea. PloS one, 9(12), e111913.

10. Espinosa C., García B.J.M., Esteban M.A. \& Cuesta A. (2018). In Vitro Effects of Virgin Microplastics on Fish Head-Kidney Leucocyte Activities. Environmental Pollution. 235:39-43.

11. Heather, W., Alexander, J., Lars, B., Margherita, B., Sandra, C., Bruce, C., \& Michael, D. (2016). Presence of Microplastics and Nanoplastics in Food, with Particular Focus on Seafood. European Food Safety Authority Journal, 14(6).

12. Hibbeln, J. R., Davis, J. M., Steer, C., Emmett, P., Rogers, I., Williams, C., \& Golding, J. (2007). Maternal seafood consumption in pregnancy and neurodevelopmental outcomes in childhood (ALSPAC study): an observational cohort study. The Lancet, 369(9561), 578-585.

13. Horton, A. A., Jürgens, M. D., Lahive, E., van Bodegom, P. M., \& Vijver, M. G. (2018). The influence of exposure and physiology on microplastic ingestion by the freshwater fish Rutilus rutilus (roach) in the River Thames, UK. Environmental Pollution, 236, 188-194.

14. Kershaw, P., Turra, A., \& Galgani, F. (2019). Guidelines for the Monitoring and Assessment of Plastic Litter in the Ocean. GESAMP reports and studies.

15. Lusher, A. L., Mchugh, M., \& Thompson, R. C. (2013). Occurrence of microplastics in the gastrointestinal tract of pelagic and demersal fish from the English Channel. Marine pollution bulletin, 67(1-2), 94-99.

16. Margaretha, A. (2019). Identifikasi mikroplastik Pada Cumi-cumi (Logilo sp) dari Beberapa Pasar
Tradisional Kota Semarang. Indonesia.

17. Mintenig, S. M., Int-Veen, I., Löder, M. G., Primpke, S., \& Gerdts, G. (2017). Identification of microplastic in effluents of waste water treatment plants using focal plane array-based micro-Fouriertransform infrared imaging. Water research, 108, 365-372.

18. Nabizadeh, R., Sajadi, M., Rastkari, N., \& Yaghmaeian, K. (2019). Microplastic pollution on the Persian Gulf shoreline: A case study of Bandar Abbas city, Hormozgan Province, Iran. Marine pollution bulletin, 145, 536-546.

19. Pace, E, Di. (1990). Proceedings of the International Conference on Water Pollution Control in the Basin of the River Danube. Water Science and Technology. 22.

20. Plastics, E. (2016). An Analysis of European Plastics Production, Demand and Waste Data. Plastics-the Facts.

21. Plastics, E. (2019). An Analysis of European Plastics Production, Demand and Waste Data. Plastics-the Facts.

22. Rochman, C. M., Tahir, A., Williams, S. L., Baxa, D. V., Lam, R., Miller, J. T., ... \& Teh, S. J. (2015). Anthropogenic debris in seafood: Plastic debris and fibers from textiles in fish and bivalves sold for human consumption. Scientific reports, 5, 14340.

23. Liebmann, B., Köppel, S., Königshofer, P., Bucsics, T., Reiberger, T., \& Schwabl, P. (2018). Assessment of microplastic concentrations in human stool: Final results of a prospective study. Environment Agency Austria.

24. Setälä, O., Fleming-Lehtinen, V., \& Lehtiniemi, M. (2014). Ingestion and transfer of microplastics in the planktonic food web. Environmental pollution, 185, 77-83.

25. Susanto, E., \& Fahmi, A. S. (2012). Senyawa fungsional dari ikan: aplikasinya dalam pangan. Jurnal Aplikasi Teknologi Pangan, 1(4).

26. Vianello, A., Jensen, R. L., Liu, L., \& Vollertsen, J. (2019). Simulating human exposure to indoor airborne microplastics using a Breathing Thermal Manikin. Scientific reports, 9(1), 1-11.

27. Wright, S.L., \& Kelly F.J. (2017). Plastic and Human Health: A Micro Issue? Environmental Science \& Technology, 51(12):34-47. 